\title{
MORFOLOGIA DE EMBRIÕES NUCELARES DE LARANJA 'VALÊNCIA' (CITRUS SINENSIS (L.) OSBECK)
}

\author{
Fernanda Januzzi Mendes-da-Glória ${ }^{1}$ \\ Francisco de Assis Alves Mourão Filho ${ }^{2,4}$ \\ Beatriz Appezzato-da-Glória ${ }^{3,4}$
}

Recebido em 22/2/2000. Aceito em 20/7/2000

\begin{abstract}
RESUMO - (Morfologia de embriões nucelares de laranja 'Valência' (Citrus sinensis (L.) Osbeck). Esse trabalho teve como objetivo avaliar a morfologia de embriões nucelares de laranja 'Valência' (Citrus sinensis (L.) Osbeck) a fim de fornecer informações para estudos de embriogênese somática induzida in vitro visando o melhoramento de citros que utilizem essa variedade. Para a realização dessas avaliações, embriões coletados de sementes provenientes de frutos maduros (13 meses após o florescimento) foram fixados, desidratados e preparados para a realização dos cortes histológicos seriados. Dos embriões avaliados, apenas um apresentou a morfologia de embrião zigótico. Os demais mostraram cotilédones com angulações e formatos distintos. Foram observados embriões mal formados com a não diferenciação de ápice caulinar e/ou ápice radicular, não desenvolvimento de um dos cotilédones, além de eixo embrionário colapsado. Os dados obtidos poderão auxiliar na interpretação dos tipos morfológicos de embriões somáticos obtidos in vitro e sua capacidade de conversão em plantas.
\end{abstract}

Palavras-chave - Citrus, anatomia, embriões nucelares

\begin{abstract}
Morphology of 'Valencia' sweet orange (Citrus sinensis (L.) Osbeck) nucellar embryos). This research work evaluated the morphology of nucellar embryos of 'Valencia' sweet orange (Citrus sinensis (L.) Osbeck), in an effort to provide this information as a reference in somatic embryo induction experiments, for in vitro breeding of this cultivar. Embryos were collected from mature fruits (13 months after blooming), and were fixed, dehydrated and prepared for serial histological cuts. Among the embryos, only one presented similar morphology to a zygotic embryo, whereas the others showed different shapes and angles in the cotyledons. Not well formed embryos were also observed, mainly due to the lack of the differentiation of the shoot apex and/or root apex, undevelopment of one of the cotyledons, or sometimes due to the collapsed embryo. The results may contribute to a better understanding of different embryo morphologies of somatic embryos and their capacity to convert in plants.
\end{abstract}

Key words - Citrus, anatomy, nucellar embryos

1 Departamento de Biotecnologia Vegetal, CENA/USP, C. Postal 96, CEP 13400-970, Piracicaba, SP, Brasil, e-mail: fjgloria@cena.usp.br

2 Departamento de Produção Vegetal, ESALQ/USP, C. Postal 9, CEP 13418-900, Piracicaba, SP, Brasil, e-mail: famourao@carpa.ciagri.usp.br

3 Departamento de Ciências Biológicas, ESALQ/USP, C. Postal 9, CEP 13418-900, Piracicaba, SP, Brasil, e-mail: bagloria@carpa.ciagri.usp.br

4 Bolsista de Produtividade em Pesquisa do CNPq 


\section{Introdução}

As plantas cítricas ocupam o primeiro lugar na produção mundial de frutos, sendo as laranjas responsáveis por $64 \%$ do volume de produção (Neves \& Boteon 1998). Por outro lado, o Brasil é o maior produtor de laranja do mundo (FAO 2000), sendo que o Estado de São Paulo produz $82 \%$ do total produzido no Brasil (Neves $\&$ Boteon 1998) e $85 \%$ do suco concentrado comercializado no mercado internacional (Neves \& Neves 1996). Apesar da posição de liderança de produção, a ocorrência de problemas fitossanitários graves como a Clorose Variegada dos Citros (CVC), o cancro cítrico, a leprose, a lagarta minadora, a gomose, o declínio, vêm ameaçando a posição mundial ocupada pela citricultura brasileira (Neves \& Boteon 1998) e acarretando muitos gastos e prejuízos ao setor citrícola. Diante dessa situação, demonstra-se a grande importância da obtenção de variedades melhoradas que apresentem tolerância a pragas e doenças para que a citricultura apresente bom desempenho, com elevada produtividade, frutos de qualidade e diminuição dos custos de produção.

Programas de melhoramento em citros vêm sendo desenvolvidos desde o século passado (Davies \& Albrigo 1994). Entretanto, os métodos convencionais que utilizam a hibridação sexual, têm apresentado pouco sucesso (SpiegelRoy \& Vardi 1984), devido a aspectos da biologia reprodutiva dos citros, como alta heterozigose, esterilidade de pólen e óvulo, incompatibilidade sexual, poliembrionia nucelar e juvenilidade (Vardi et al. 1974; Ling et al. 1989; Grosser \& Gmitter Junior 1990).

Técnicas biotecnológicas podem ser uma opção para que as limitações relacionadas à biologia reprodutiva dos citros, que dificultam a obtenção de variedades melhoradas através de métodos convencionais de melhoramento, sejam superadas. Maiores possibilidades de sucesso no melhoramento dos citros podem ser conseguidas pelo desenvolvimento de programas que asso- ciem métodos convencionais de melhoramento a essas novas técnicas (Grosser \& Gmitter Junior 1990).

A hibridação somática via fusão de protoplastos de variedades com características complementares tem se tornado muito importante em programas de melhoramento genético de citros. Atualmente existem mais de 100 híbridos somáticos de citros, sendo que a grande maioria deles foi regenerado via embriogênese somática (Grosser et al. 1996). Outra técnica com grande potencial de utilização no melhoramento de citros é a transformação genética, para a qual a embriogênese somática é muito importante para a regeneração de plantas a partir de calo transformado (Grosser 1994).

Ambas as técnicas utilizam a embriogênese somática na regeneração de plantas, sendo esse processo relatado nos citros desde a década de 60 (Dunstan et al. 1995). Entretanto, a embriogênese somática in vitro de citros não é bem caracterizada, já que desde os primeiros trabalhos, como o de Rangan et al. (1968), a taxa de sucesso no desenvolvimento de embriões era baixa, chegando a $20-30 \%$ em alguns tratamentos. Esse tipo de problema foi também mencionado por Gmitter Junior \& Moore (1986), que relatam o aparecimento de grande número de embriões somáticos obtidos in vitro com anormalidades de desenvolvimento, os quais, em função do grau de má formação, não eram convertidos em plantas. Mais recentemente, Ling \& Iwamasa (1997) relataram conversão de embriões em plantas de gêneros parentes dos Citrus de apenas $23,4 \%$. O problema de baixa taxa de conversão em plantas foi observado também por Mendes-da-Glória (1998) em trabalhos de hibridação somática.

Estudos de embriogênese somática têm mostrado uma relação positiva entre aberrações morfológicas e a baixa conversão de embriões somáticos em plantas, como amendoim (Wetzstein \& Baker 1993), cenoura (Nickle \& Yeung 1994), noz-pecan (Rodriguez \& Wetzstein 1994), batata-doce (Padmanabhan et al. 1998), 
uva (Passos et al. 1999) e soja (Fernando 1999). Com intuito de otimizar a embriogênese somática em outras espécies, vem se tornando cada vez mais comum a comparação da embriogênese zigótica e somática. Em citros, a possibilidade de se comparar o processo de embriogênese somática nucelar e a embriogênese somática induzida in vitro parece ainda mais atraente, já que estão sendo comparadas morfologias de embriões obtidos a partir de células somáticas.

Desta forma, esse trabalho teve como objetivo avaliar características anatômicas de morfologias distintas de embriões nucelares de laranja 'Valência' (Citrus sinensis (L.) Osbeck), a fim de gerar informações a serem utilizadas na otimização de protocolos de embriogênese somática de citros, através da seleção de tipos morfológicos passíveis de conversão em plantas, visando assim contribuir para a eficiência de obtenção de plantas melhoradas via hibridação somática e via transformação genética, já que esta última depende de um protocolo altamente eficiente de regeneração de plantas in vitro.

\section{Material e métodos}

Os embriões nucelares encontrados em aproximadamente 40 sementes coletadas de frutos maduros (13 meses após o florescimento) de laranja 'Valência' (Citrus sinensis (L.) Osbeck) foram fixados na solução de Karnovsky (Karnovsky 1965) e a desidratação foi feita em série alcoólica-etílica. Os embriões foram infiltrados com historesina glicol-metacrilato da Reichert-Jung. Foram feitos cortes seriados dos embriões com espessura de $5 \mu \mathrm{m}$, e as seções foram coradas com solução contendo $0,05 \%$ de azul de toluidina em $0,15 \mathrm{M}^{\text {de }} \mathrm{K}_{2} \mathrm{PO}_{4}$ (Sakai 1973).

As lâminas foram fotomicrografadas com auxílio de fotomicroscópio NIKON AFX-DX, utilizando-se filmes Kodak Gold ISO 100 e TMAX ISO 100.

\section{Resultados e discussão}

Embriões de citros, segundo Frost \& Soost (1968), apresentam cotilédones carnosos, que constituem a maior parte do embrião maduro, inseridos no hipocótilo pequeno. Na semente monoembriônica de citros, geralmente o embrião possui dois cotilédones com tamanho e formato praticamente iguais. Durante a coleta de material a ser analisado no presente estudo, encontrou-se uma semente que continha apenas um embrião (Fig. 1 a 3). Acredita-se que esse embrião, pela morfologia dos cotilédones e do eixo embrionário não anguloso, no qual estão diferenciados os ápices meristemáticos caulinar e radicular, seja de origem zigótica. Entretanto, a laranja 'Valência' é uma variedade poliembriônica, ou seja, que produz embriões extras, derivados não de células do saco embrionário, mas de células somáticas do nucelo, que desenvolvem-se no óvulo lado a lado com o embrião zigótico. Esses embriões são também chamados de embriões nucelares (Frost \& Soost 1968).

Os demais embriões coletados e avaliados no presente estudo eram de origem nucelar, com formas e tamanhos muito diferentes, características também encontradas em sementes poliembriônicas de citros (Frost \& Soost 1968) e de Aspidosperma polyneuron M. Arg. (Souza \& Moscheta 1992).

Segundo Koltunow (1993), o desenvolvimento de embriões nucelares é morfologicamente similar, se não idêntico, aos estágios de desenvolvimento de embriões sexuais em Citrus, podendo-se esperar embriões nucelares morfologicamente parecidos. Porém, no presente estudo foram encontrados embriões nucelares morfologicamente distintos em uma mesma semente e em diferentes sementes de laranja 'Valência'. Parte desta variação morfológica poderia ser explicada pela competição por espaço no interior da semente, por exemplo, cotilédones com angulações (Fig. 5 e 8), eixo embrionário colapsado (Fig. 8 e 9) e embriões anisocotiledonares (Fig. 11). 

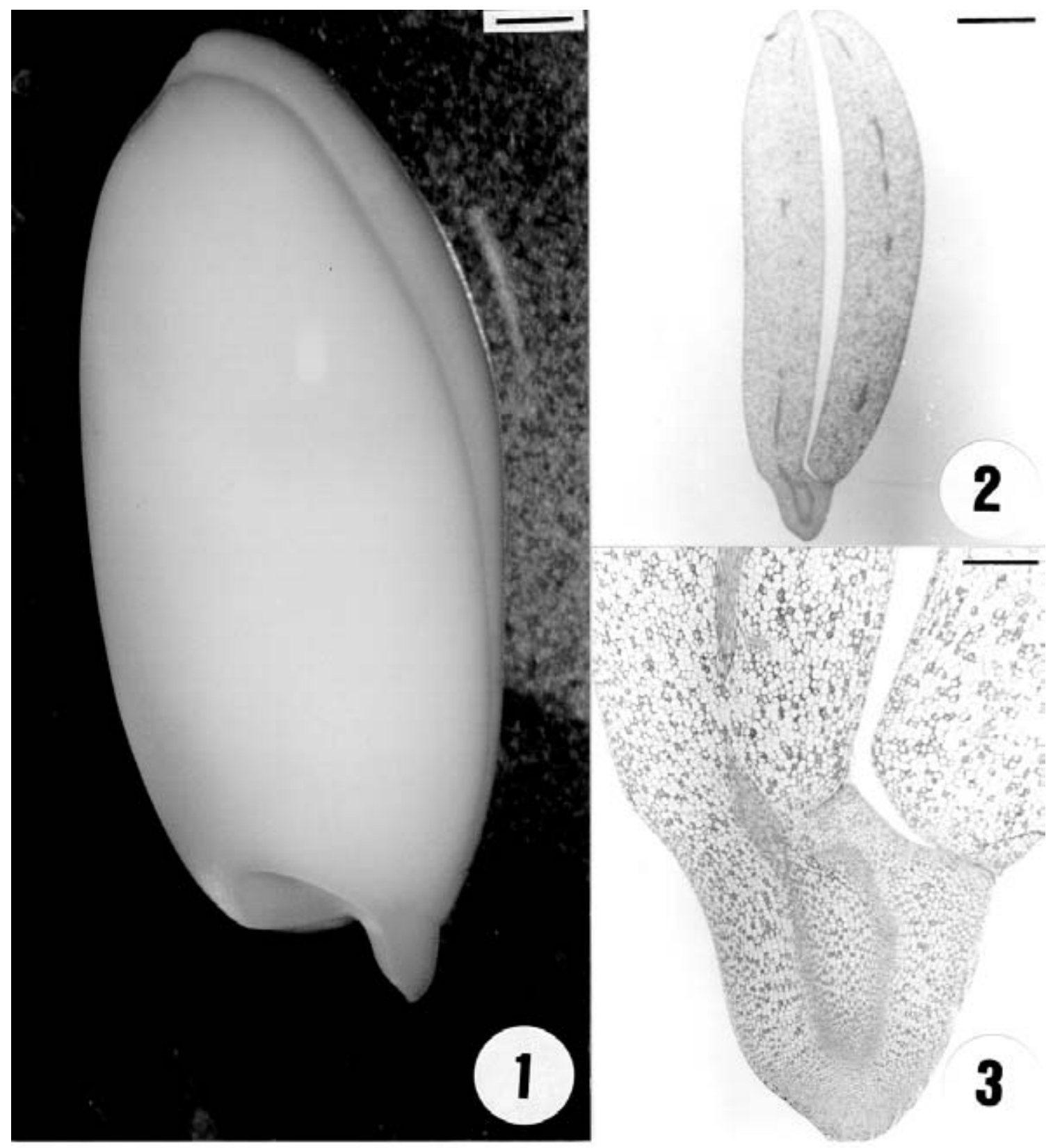

Figuras 1-3. 1. Morfologia externa de um embrião de laranja 'Valência' (barra $=870 \mu \mathrm{m})$; 2-3. cortes longitudinais do embrião da fig. 1; 2. visão geral do embrião, mostrando os cotilédones e o eixo embrionário não angulosos (barra $=$ $1,5 \mathrm{~mm}) ; 3$. detalhe do eixo embrionário (barra $=552 \mu \mathrm{m}$ ). 


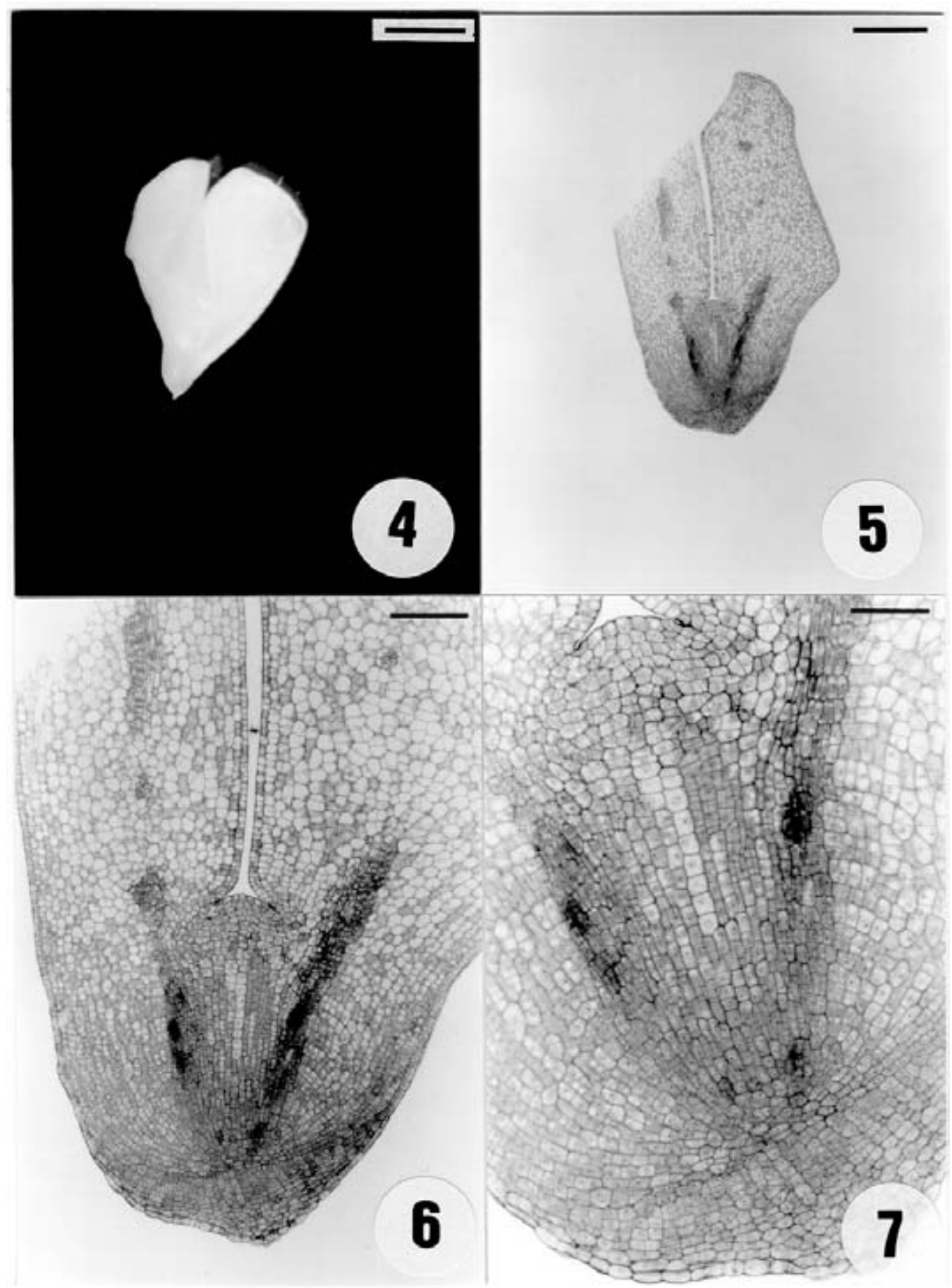

Figuras 4-7. 4. Morfologia externa de um embrião nucelar de laranja 'Valência' (barra $=870 \mu \mathrm{m})$; 5-7. cortes longitudinais do embrião nucelar da fig. 4; 5. visão geral do embrião, mostrando o eixo embrionário e cotilédones com angulações $($ barra $=552 \mu \mathrm{m}) .6-7$. detalhes dos cotilédones e eixo embrionário, mostrando os meristemas apicais caulinar e radicular bem diferenciados (barras $=205 \mu \mathrm{m}$ e $102 \mu \mathrm{m}$, respectivamente). 


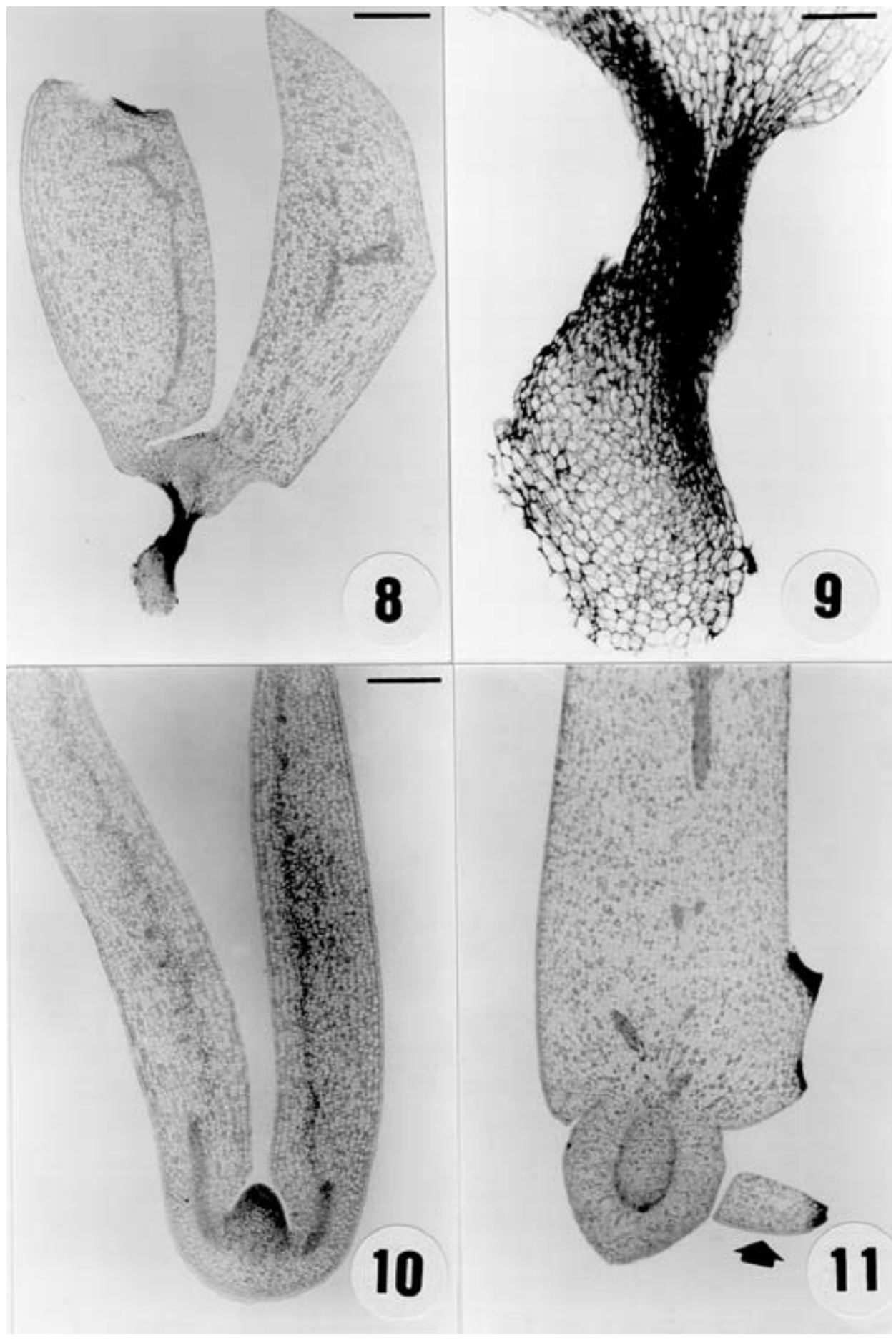

Figuras 8-11. 8-10. Cortes longitudinais de embriões nucelares mal-formados de laranja 'Valência'; 8. visão geral de um embrião com o eixo embrionário colapsado $($ barra $=205 \mu \mathrm{m})$; 9 . detalhe do eixo embrionário colapsado, mostrando as células obliteradas (barra $=53 \mu \mathrm{m}$ ); 10. visão geral de um embrião nucelar desprovido de ápice radicular, porém com cotilédones e ápice caulinar bem diferenciados (barra $=552 \mu \mathrm{m})$; 11 . embrião com um dos cotilédones atrofiados (seta) (barra $=552 \mu \mathrm{m}$ ). 


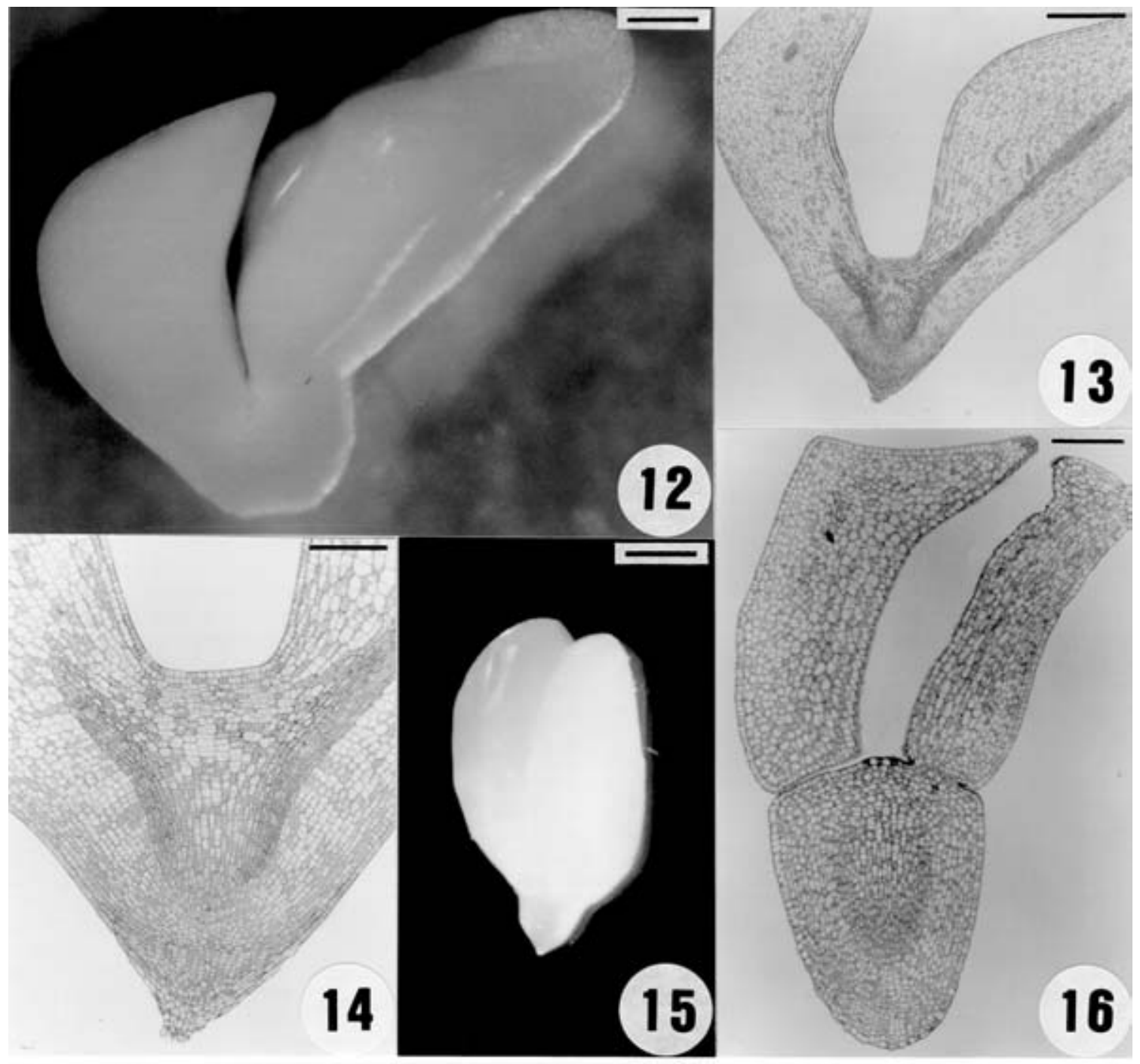

Figuras 12-16. 12. Morfologia externa de um embrião nucelar de laranja 'Valência' com estrutura atípica (barra $=238 \mu \mathrm{m}$ ); 13-14. cortes longitudinais do embrião nucelar mostrado na fig. 12, cujo eixo embrionário apresenta o ápice caulinar não diferenciado (barras $=552$ e $205 \mu \mathrm{m}$, respectivamente); 15. morfologia externa de um embrião nucelar de laranja 'Valência' com estrutura atípica $($ barra $=870 \mu \mathrm{m}) ; 16$. corte longitudinal do embrião que não apresenta a diferenciação dos pólos caulinar e radicular (barra $=205 \mu \mathrm{m})$. 
Outra alteração morfológica encontrada foi a falta de desenvolvimento do ápice caulinar e/ ou radicular. Na Fig. 10, observa-se um embrião com cotilédones e ápice caulinar bem desenvolvidos. Entretanto, não ocorreu a diferenciação da região radicular desse embrião. Por outro lado, nas Fig. 12 a 14, o embrião nucelar, embora apresente o ápice radicular bem diferenciado, o ápice caulinar é do tipo juvenil (Liu et al. 1993). As análises seriadas de um embrião morfologicamente similar ao mostrado na Fig. 15 , permitiram observar a ausência de diferenciação dos ápices caulinar e radicular. Um destes cortes está representado na Fig. 16.

Estudos envolvendo a regeneração de plantas via embriogênese somática in vitro em diferentes culturas têm apontado o surgimento de embriões somáticos com anormalidades de desenvolvimento e más-formações, que variam bastante em função do gênero e espécie estudados, além da influência exercida também pelo tratamento in vitro. Dentre as alterações observadas, os embriões somáticos diferem principalmente em relação à morfologia do meristema apical caulinar e dos cotilédones. Trabalhos envolvendo o cultivo e conversão de embriões somáticos em plantas em diferentes culturas (Wetzstein \& Baker 1993; Nickle \& Yeung 1994; Rodriguez \& Wetzstein 1994; Padmanabhan et al. 1998; Passos et al. 1999; Fernando 1999) têm relacionado a baixa taxa de conversão com as anormalidades presentes no meristema apical caulinar dos embriões.

Dentre as más-formações observadas nos embriões do presente estudo, as que poderiam estar relacionadas à baixa taxa de conversão em plantas, são o eixo embrionário colapsado (Fig. 8 e 9) e o não desenvolvimento do meristema apical caulinar (Fig. 12 a 16).

A partir de sementes germinadas, foram observadas plântulas com cotilédones de tamanhos bastante diferentes (dados não mostrados), indicando que a presença de embriões com cotilédones angulosos e de tamanhos distintos são características morfológicas que não afetam a conversão destes em plantas.

No caso de variedades poliembriônicas do gênero Citrus, a presença de embriões nucelares com problemas de desenvolvimento descritos neste trabalho poderia explicar porque o número médio de plântulas germinadas por semente (2-3) é comumente bem inferior ao número total de embriões (Frost \& Soost 1968).

Com os resultados obtidos neste trabalho, foi possível observar a morfologia de um embrião típico de laranja 'Valência' e as variações morfológicas encontradas em embriões nucelares desta mesma variedade. Deste modo, estes dados poderão ser úteis na avaliação da morfologia de embriões somáticos e da sua capacidade de conversão em plantas.

\section{Referências bibliográficas}

Davies, F. \& Albrigo, L. 1994. Citrus. CAB International, Wallingford.

Dunstan, D. I.; Tautorus, T. E. \& Thorpe, T. A. 1995. Somatic embryogenesis in woody plants. Pp. 471538. In: T. A. Thorpe (Ed.), In vitro embryogenesis in plants. Kluwer Academic, Dordrecht.

FAO. FAOSTAT - Statistics Database. http:// apps.fao.org. (20 Jan. 2000).

Fernando, J. A. 1999. Estudos anatômicos da embriogênese somática in vitro em soja (Glycine $\max ($ L.) Merrill). Dissertação de Mestrado. Universidade de São Paulo, Piracicaba.

Frost, H. B. \& Soost, R. K. 1968. Seed reproduction: development of gamets and embryos. Pp. 290-324. In: W. Reuther; L. D. Batchelor \& H. J. Webber (Eds.), The citrus industry. University of California, Riverside.

Gmitter Junior, F. \& Moore, G. 1986. Plant regeneration from undeveloped ovules and embryogenic calli of Citrus: embryo production, germination and plant survival. Plant Cell, Tissue and Organ Culture 6: $139-147$.

Grosser, J. W. 1994. In vitro culture of tropical fruits. Pp. 475-496. In: I. K. Vasil \& T. A. Thorpe (Eds.), Plant Cell and Tissue Culture. Kluwer Academic, Dordrecht.

Grosser, J. W. \& Gmitter Junior, F. G. 1990. Protoplast fusion and citrus improvement. Plant Breeding Reviews 8: 339-374. 
Grosser, J. W.; Gmitter Junior, F. G.; Tusa, N.; Reforgiato Recupero, G. \& Cucinotta, P. 1996. Further evidence of a hybridization requirement for plant regeneration from citrus leaf protoplasts following somatic fusion. Plant Cell Reports 15: 672-676.

Karnovsky, M. J. 1965. A formaldehyde-glutaraldehyde fixative of high osmolality for use in electron microscopy. Journal of Cell Biology 27: 137-138.

Koltunow, A. M. 1993. Apomixis: embryo sacs and embryo formed without meiosis or fertilization in ovules. The Plant Cell 5: 1425-1437.

Ling, J. T.; Nito, N. \& Iwamasa, M. 1989. Plant regeneration from protoplasts of Calamondin (Citrus madurensis Lour.). Scientia Horticulturae 39: 325-333.

Ling, J. T. \& Iwamasa, M. 1997. Plant regeneration from embryogenic calli of six Citrus related genera. Plant Cell, Tissue and Organ Culture 49: 145-148.

Liu, C. M.; Xu, Z. H. \& Chua, N. H. 1993. Proembryo culture: in vitro development of early globular-stage zygotic embryos from Brassica juncea. Plant Journal 3: 291-300.

Mendes-da-Glória, F. J. M. 1998. Hibridação somática entre laranja 'Caipira' e limão 'Cravo' através de fusão de protoplastos. Dissertação de Mestrado. Universidade de São Paulo, Piracicaba.

Neves, E. M. \& Boteon, M. 1998. Impactos alocativos e distributivos na citricultura. Preços Agrícolas 12(136): 3-6.

Neves, E. M. \& Neves, M. F. 1996. Suco concentrado de laranja: uma comodity "sui generis". Preços Agrícolas 10(119): 11-13.

Nickle, T. C. \& Yeung, E. C. 1994. Further evidence of a role for abscisic acid in conversion of somatic embryos of Daucus carota. In Vitro Cell Development Biology 30: 96-103.

Padmanabhan, K.; Cantliffe, D. J. \& Harrell, R. C. 1998. A comparison of shoot-forming and non-shoot-forming somatic embryos of sweet potato [Ipomoea batatas (L.) Lam.] using computer vision and histological analyses. Plant Cell Reports 17: 685-692.
Passos, I.; Appezzato-da-Glória, B. \& Vieira, M. L. C. 1999. Embryogenic responses of Vitis spp: effects of genotype and polyvinylpyrrolidone. Vitis 38(2): 47-50.

Rangan, T. S.; Murashige, T. \& Bitters, W. P. 1968. In vitro initiation of nucellar embryos in monoembryonic Citrus. HortScience 3(4): 226227.

Rodriguez, A. P. M. \& Wetzstein, Y. H. 1994. The effect of auxin type and concentration on pecan (Carya illinoinensis) somatic embryo morphology and subsequent conversion into plants. Plant Cell Reports 13: 607-611.

Sakai, W. S. 1973. Simple method for differential staining of paraffin embedded plant material using toluidine blue O. Stain Technology 48: 247-249.

Souza, L. A. \& Moscheta, I. S. 1992. Morfo-anatomia dos frutos e da plântula de Aspidosperma polyneuron M. Arg. (Apocynaceae). Revista Brasileira de Biologia 52(3): 439-447.

Spiegel-Roy, P. \& Vardi, A. 1984. Citrus. Pp.355-372. In: P. V. Amirato; D. A. Evans; W. R. Sharp \& Y. Yamada (Eds.), Handbook of plant cell culture. Macmillan Co., New York.

Vardi, A.; Spiegel-Roy, P. \& Galun, E. 1974. Citrus cell culture: isolation of protoplasts, plating densities, effect of mutagens and regeneration of embryos. Plant Science Letters 4: 231-236.

Wetzstein, H. Y. \& Baker, C. M. 1993. The relationship between somatic embryo morphology and conversion in peanut (Arachis hypogaea L.). Plant Science 92: 81-89. 